\title{
Pathogenic bacteria associated with cutaneous canine myiasis due to Cordylobia anthropophaga
}

\author{
Chukwu Okoh Chukwu' ${ }^{1}$ Ndudim Isaac Ogo ${ }^{2}$, Abdulazeez Jimoh ${ }^{1}$, Doris Isioma Chukwu ${ }^{3}$ \\ 1. Dept. of Medical Microbiology, Federal College of Veterinary and Medical Laboratory Sciences, National \\ Veterinary Research Institute, Vom, Plateau State, Nigeria. 2. Parasitology Division, National Veterinary \\ Research Institute, Vom, Plateau State, Nigeria. 3. Central Diagnostic Laboratory, National Veterinary \\ Research Institute, Vom, Plateau State, Nigeria. \\ Corresponding author: Ndudim Isaac Ogo, E-mail: ogoendy@yahoo.com; Tel: +2348034521514. \\ Received: 25-03-2012, Accepted: 10-05-2012, Published Online: 30-07-2012 \\ doi: $10.5455 /$ vetworld.2012.617-620
}

\begin{abstract}
Aim: The study was designed to evaluate the common pathogenic bacteria associated with cutaneous canine myiasis caused by Cordylobia anthropophaga, and their prevalence in relation to breed, sex and age of the infested dogs.

Materials and Methods: A total of one hundred and thirty three (133) myiasis wound swabs and Cordylobia anthropophaga larvae were collected from infested dogs and analyzed for pathogenic bacteria using microscopic, cultural and biochemical methods.

Results: The most commonly encountered bacteria were Staphylococcus aureus 75 (56.4\%), Streptococcus spp. 16 (12\%) and Escherichia coli 7 (5.3\%). Other organisms isolated include, Staphylococcus epidermidis and Corynebacteria species, while mixed infection of $S$. aureus and Streptococcus spp were also observed. The rate of infection was found to be highest among the age groups 1-20 weeks and least in the $91-100$ (week) age groups. The breed of dogs mostly infected with these bacteria was the local breed (Mongrel) while the German shepherd /Alsatian breeds were the least infected and with 58.6\% (78) and $4.5 \%$ (6) percentage respectively. Male dogs showed more propensities to bacterial infection of all the types isolated and accounted for $60.9 \%$ (81) in contrast to the female dogs with $39.11 \%$ (52) infection rate. Pure bacteria isolates were frequently encountered $94.7 \%$ (126), while mixed infection accounted for just $5.3 \%$ (7).

Conclusion: Our results indicates that several pathogenic and zoonotic bacteria are associated with C. antropophaga myiasis in dogs, and should serve as concern for pet owners and veterinarians.

Keywords: Cordylobia anthropophaga, dog, myiasis, pathogenic bacteria
\end{abstract}

To cite this article:

Chukwu CO, Ogo NI, J imoh A, Chukwu DI (2012) Pathogenic bacteria associated with cutaneous canine myiasis due to Cordylobia anthropophaga, Vet World, 5(10): 617-620, doi: 10.5455/vetworld.2012.617-620

\section{I ntroduction}

Myiasis is the infestation of human and vertebrate animals with the larval stages of Dipterian flies, and is known to occur facultatively or obligatorily. The infestation occurs at various sites of the body such as eyes, intestine, mouth, nose, urinogenital tract and brain where they survive and cause damages by feeding on dead or living tissues, ingested food or liquid body substances [1,2].

Dipteran flies that have been known to cause canine myiasis include; Cordylobia anthropophaga, Dermatobia hominis, Cochliomyia hominivorax, Oestrus ovis and Phormia sericatus. These flies are widespread in the tropics and subtropics of Africa and the Americas, but occur with less frequency in other areas of the world. Canine myiasis as in other animals could be obligatory in that the larvae invades fresh and uncontaminated skin wounds, or facultative in which case the larvae are linked with bacteria contaminated skin wounds and or faeces matted hair coat $[3,4]$.

Clinical signs associated with canine myiasis include numerous erythematous and furunculoid skin lesions which oozes out serous fluid, application of pressure on such lesions leads to the expulsion of the larva(e) with liquefied hemorrhagic or purulent tissues which may be contaminated with microorganisms [5,6].

While a significant number of bacteria in cutaneous myiasis of domestic animals are caused by opportunistic pathogens of the skin flora, others are caused by opportunistic bacterial pathogens inoculated into the skin by arthropod ectoparasites and opportunistic pathogens from the unhygienic environment [7].

The knowledge of zoonotic bacteria of public health importance in cutaneous canine myiasis has not been reported in Nigeria, in this study, an evaluation of the common pathogenic bacteria associated with 
Pathogenic bacteria associated with cutaneous canine myiasis due to Cordylobia anthropophaga

Table-1. Percentage distribution of bacteria with age-group of dogs

\begin{tabular}{|c|c|c|c|c|c|c|c|c|}
\hline Ages (Weeks) & S. aureus & S. epidermidis & Streptococcus spp. & E. coli & Corrynebacteria spp. & $\begin{array}{c}\text { S. aureus } \\
\text { Streptococcus spp. }\end{array}$ & Total & $\begin{array}{l}\text { \% infection/ } \\
\text { Age-group }\end{array}$ \\
\hline $1-10$ & 46 & 10 & 8 & 6 & 5 & 4 & 78 & $58.6 \%$ \\
\hline $11-20$ & 17 & 5 & 6 & 1 & 2 & 2 & 33 & $24.8 \%$ \\
\hline $21-30$ & 2 & 1 & - & - & - & - & 3 & $2.3 \%$ \\
\hline $31-40$ & 2 & - & - & - & 1 & 1 & 4 & $3.0 \%$ \\
\hline $41-50$ & 2 & - & 1 & - & - & 1 & 4 & $3.0 \%$ \\
\hline $51-60$ & 2 & - & - & - & - & - & 2 & $1.5 \%$ \\
\hline $61-70$ & - & - & - & - & - & - & - & - \\
\hline $71-80$ & 4 & - & 1 & - & 1 & - & 6 & $4.5 \%$ \\
\hline $81-90$ & & - & - & - & - & - & & \\
\hline $91-100$ & 1 & 2 & - & - & - & - & 3 & $2.3 \%$ \\
\hline
\end{tabular}

Cutaneous myiasis caused by Cordylobia anthropophaga was assayed based on breed, sex and age of myiasis infested dogs.

\section{Materials and Methods}

Survey and sample collection: A total of $133 \mathrm{swab}$ samples from dogs with Cutaneous myiasis wounds were collected from three major veterinary clinics in Plateau State, Nigeria: The Veterinary Clinic, National Veterinary Research Institute, Vom, ECWA Veterinary Clinic, Bukuru, and Plateau State Veterinary Clinic, Polo field Jos.

Papules and pustules suspected of containing larvae were swabbed with $70 \%$ ethanol before applying pressure to the base of each papule to express the larva and subsequently remove it with sterile forceps. Sterile cotton was used to swab the surface of each larva and lesion. Each swab sample was inoculated into a Brain Heart infusion broth and placed in a cold box while the larvae were put in $10 \mathrm{~mL}$ bijou bottles and transported to the Bacteriology Division and Parasitology Division laboratories of the National Veterinary Research Institute, Vom, Nigeria for analysis and larval identification.

Bacteriologic and parasitologic investigations: Bacteriological analysis included isolation of possible potential pathogens according to standard procedures of American Public Health Association (APHA) (1992). Briefly, the myiasis lesion was swabbed with a sterile swab and inoculated into Brain Heart infusion broth ( $\mathrm{pH}$ : $7.2 \pm 0.2$ ). Bacteria were mechanically removed by shaking the broth. The swab in the culture broth was incubated at $37^{\circ} \mathrm{C}$ for $24-48$ hours; this was followed by streaking a loopful of the broth onto blood agar (BA) (Oxoid), MacConkey agar (MCA) and Deoxycholate Citrate agar (DCA) and then incubated at $37^{\circ} \mathrm{C}$ for $24-48$ hours.

After the observation of the colonial characteristics of the potential bacterial organisms on the different solid media agar plates were made, the suspect organisms were further identified based on their microscopic, physiological and biochemical characteristics according to Barrow et al., [8].

Identification of the larvae was carried out using the posterior spiracular plate method [9]. In brief, each larva was boiled in $10 \%$ potassium hydroxide for 5 minutes and the posterior spiracle cut to a depth of about $1 \mathrm{~mm}$. Excess tissue around the plate was teased out before being dehydrated in varying concentrations of alcohol $(70-100 \%)$. Zylene cleaning took place before DPX mounting and observation under the dissecting and light microscopes.

\section{Results}

Of the one hundred and thirty three samples screened, five bacterial species were identified and in the following order of abundance; Staphylococcus aureus 75 (56.4\%), Staphylococcus epidermidis 18 (13.5\%), Streptococcus spp 16 (12.0\%), Corynebacteria spp $9(6.8 \%)$ and Escherichia coli 7 (5.3\%). Mixed infection of Staphylococcus spp and Streptococcus spp accounted for $8(6.0 \%)$. We recorded Staphylococcus spp infection in all age groups whereas infection due to E. coli was limited to the 1-20 weeks age bracket.

Table 1 shows the distributions of bacteria with age groups of dogs. The incidence of bacteria was high within the age bracket 1-10 weeks and low in age bracket 91-100 weeks. Generally incidence of pathogenic (Staphylococcus aureus) and non pathogenic (Staphylococcus epidermidis) bacteria decreased with age.

Table 2 shows the percentage distribution of all the bacteria isolated among various breeds of dogs. Mongrel (local breed) had the highest $(58.6 \%)$ and German shepherd the lowest (4.5\%). Staphylococcus aureus and Streptococcus species were isolated in almost all the breeds of dogs. Table- 3 shows percentage distribution of isolated bacteria according to the sex of dogs. Males were mostly infected with a total of $60.9 \%$ and female least with $39.1 \%$.

Parasitological examination revealed that all the larvae examined were identified as Cordylobia anthropophaga larvae. 
Pathogenic bacteria associated with cutaneous canine myiasis due to Cordylobia anthropophaga

Table-2. Distribution of bacteria among breeds of dogs and percentage isolation rate of bacteria

\begin{tabular}{|c|c|c|c|c|c|c|c|c|}
\hline Breeds & S. aureus & S. epidermidis & Streptococcus spp. & E. coli & Corrynebacteria spp. & $\begin{array}{c}\text { S. aureus } \\
\text { Streptococcus spp. }\end{array}$ & Total & $\begin{array}{l}\% \text { infection/ } \\
\text { Age-group }\end{array}$ \\
\hline Mongrel & 44 & 8 & 11 & 4 & 5 & 6 & 78 & $58.65 \%$ \\
\hline Rottweiler & 6 & 3 & 1 & - & 1 & 1 & 12 & $9.02 \%$ \\
\hline Caucasian & 8 & 1 & 1 & 2 & - & - & 12 & $9.02 \%$ \\
\hline Boxers & 5 & 2 & 1 & - & 1 & 1 & 10 & $7.52 \%$ \\
\hline Germ/Als & 4 & 0 & 1 & - & 1 & - & 6 & $4.51 \%$ \\
\hline
\end{tabular}

Table-3. Percentage Distribution of bacteria with sex of dog

\begin{tabular}{lccccccc}
\hline Sex & S. aureus & $\begin{array}{c}\text { Non pathogenic } \\
\text { Streptococcus. Spp. }\end{array}$ & Streptococcus spp. & E. coli & Corrynebacteria spp. & $\begin{array}{c}\text { S. aureus } \\
\text { Streptococcus spp. }\end{array}$ & $\begin{array}{c}\text { Total } \\
\text { \% infection/ } \\
\text { Age-group }\end{array}$ \\
\hline Male & 48 & 13 & 9 & 2 & 4 & 4 & 80 \\
Female & 27 & 5 & 7 & 5 & 5 & 4 & $50.2 \%$ \\
\hline
\end{tabular}

\section{Discussion}

All the larvae samples isolated from dogs with myiasis in this study were identified as Cordylobia anthropophaga larvae, and this is in tandem with the results obtained in the same study area by Ogo, et al., [9].

Of the total 133 samples screened, 75 (56.4\%) were found to be positive for pathogenic Staphylococcus aureus, 18 (13.5\%) for non-pathogenic Staphylococcus epidermidis and 16(12.0\%) for Streptococcus species.

Most of the organisms isolated from the wounds and larvae in this study have been incriminated in pyogenic dermatitis of dogs [10], thus the possibility of dogs with concurrent myiasis infestation and any predisposing factor such as endocrine in-balance, metabolic disorders or immune deficiencies may lead to pyogenic dermatitis. Results from our investigation show that incidence of pathogenic bacteria or opportunistic pathogens decrease as the age of the dogs increase, this is especially so with streptococcal and staphylococcal infections which have been shown to infect puppies and older dogs as a result of their not fully developed and declining immune system respectively $[11,12]$. The age categorization adopted by Greeley, et al., [13] in accessing "the influence of age on the canine immune system" (young = mean 2.4 years; middle-aged $=$ mean 5.8 years and old $=$ mean 9.1 years) shows that all the dogs sampled in our study fell within the age range for young dogs, thus explaining the results obtained.

While age-related susceptibility to certain bacteria infection has been documented by several authors $[11,13,14]$, literatures on breed predisposition to bacteria infection is scarce.

In our study, local breeds of dogs (Mongrels) were found to be more infected $(58.65 \%)$ by various bacteria and Staphylococcus aureus in particular. This observation has not been encountered in literatures, but may be due to the low value placed on the breed and the resultant neglect in care and nutrition, thus exposing them to myiasis infestation and bacteria infection. Other breeds of dogs encountered in this study are of foreign origin, expensive and well catered for, and this may explain the low infection rates for the various organisms encountered. Also, of the total samples screened male dogs were observed to be more infected with pathogens with percentage of $60.2 \%$ (80) than female dogs which had $39.8 \%$ (53). From these figures Staphylococcus aureus infection was observed in a total of 48 male and 26 females respectively.

Although Staphylococcus spp, Streptococcus spp, Corynebacteria spp and Escherichia coli amongst others are considered as normal / transient bacteria in canine skin, they have been known to play a role as secondary pathogens [10], and the propensity for these organisms to become pathogenic is heightened when they gain entrance into the skin as is the case with myiasis and other conditions that promote bacterial adherence and colonization [15]. Even though the strain of Staphylococcus aureus isolated in our study was not typed to determine its status, it is pertinent to note that the isolation of the Methicillin-Resistant Staphylococcus aureus (MRSA) strain from dogs has been reported $[16,17]$ and should serve as a concern to both the veterinarians and pet owners.

\section{Author's contribution}

COC and NIO conceived and designed the project, involved in the identification of the larvae, drafted the manuscript. AJ and DIC collected the samples and conducted some aspects of the studies. All authors read and approved the final manuscript.

\section{Acknowledgements}

We are grateful to the Provost, Federal College of Veterinary and Medical Laboratory Sciences, 
National Veterinary Research Institute, Vom, Plateau State, Nigeria for supporting this work.

\section{Competing interests}

Authors declares that they have no competing interest.

\section{References}

1. Caissie, R., Beaulieu, F., Giroux, M., Berthod, F., and Landry, P. (2008): Cutaneous Myiasis: Diagnosis, Treatment, and Prevention. J Oral Maxillofac Surg. 66:560-568.

2. Schnur, H.J., Zivotofsky, D., and Wilamowski, A. (2009): Myiasis in domestic animals in Isreal. Vet. Parasitol. 161:352-355.

3. Tuygun, N., Taylan-Ozkan, A., Tanir, G., and Kosta Y. Mumcuoglu K.Y. (2009): Furuncular myiasis in a child caused by Wohlfahrtia magnifica. (Diptera: Sarcophagidae) associated with eosinophilia. The Turk. J.Ped. 51: 279-281.

4. Guimaraes, J.H. and Papavero, N. (1998). Myiasis caused by obligatory parasites. In GUIMARAES, J. H.; N. PAPAVERO. Myiasis in man and animals in the Neotropical region - bibliographic database. Sao Paulo: Plaide. 1998. p. 257.

5. Hohenstein, E.J. and Buechner, S.A. (2004). Cutaneous myiasis due to Dermatobia hominis. Dermatol. 208: 268-270.

6. Robbins, K., and Khachemoune, A. (2010): Cutaneous myiasis: a review of the common types of myiasis. Int. J. Dermatol. 49:1092-1098.

7. Jawetz, E., Melnick, J.K. and Adelberg, A.E. (2001). Medical microbiology $22^{\text {nd }}$ edition, Lange medical book/mc Graw Hill p 301 - 304.

8. Barrow, I.G., Steel, K.Y. and Fetahn, A.K.R. (1993). Cowan and Steelis manualfor the identification of medical bacteria $3^{\text {rd }}$ edition, Cambridge University
Press, Cambridge New York.

9. Ogo, I.N., Onovoh, E., Ayodele, D.R., Ajayi, O.O., Chukwu, C.O., Sugun, M. and Okeke, I.O (2009). Cutaneous canine myiasis in the Jos metropolis of Plateau State, Nigeria, associated with Cordylobia anthropophaga. Vet. Arhiv. 79(3): 293-299.

10. Cherni, J.A., Boucher, J.F., Skogerboe, T.L., Tarnacki, S., Gajewski, K.D., Cynthia J. Lindeman, C.J. (2006): Comparison of the Efficacy of Cefpodoxime Proxetil and Cephalexin in Treating Bacterial Pyoderma in Dogs. Intern J Appl Res Vet Med. 4: 85-93.

11. Strasser, A., Teltscher, A., May, B., Sanders, C. and Niedermuller, H. (2000). Age-associated changes in the immune system of German Shepherd dogs. J. Vet. Med. 47: 181-192.

12. Hogenesch, H. and Thompson, S. (2010). Effect of ageing on the immune response of dogs to vaccines. $J$. comp. path. 142: S74-S77.

13. Greeley, E.H., Kealy, R.D., Ballam, J.M., Lawler, D.F. and Segre, M. (1996). The influence of age on the canine immune system. Vet. Immunol. Immunopathol. 55: $1-10$.

14. Gervais, F., Patel, P. and Skamene, E., (1988). Increased natural resistance to Listeria monocytogenes in senescent mice correlates with enhanced macrophage bactericidal activity. J. Gerontol. 43:B152-B156.

15. McEwan NA: Adherence by Staphylococcus intermedius to canine keratinocytes in atopic dermatitis. Res Vet Sci 2000;68:279-283.

16. Baptise, K.E., Williams, K., Williams, N.J., Wattret, A. and Clegg, P.D. (2005). Methicilin-resistant staphylococci in companion animals. Emerg. Infect. Dis. 11: 1942-1944.

17. Faires, M.C., Traverse, M., Tater, K.C., Pearl, D.L. and Weese, J.S. (2010). Methicilin-Resistant and Susceptible Staphylococcus aureus infections in dogs. Emerg. Infec. Dis. 16: 69-75. 